Pediat. Res. 3: 579-589 (1969)

Blood glucose infants

creatinine excretion insulin

growth hormone marasmus

\title{
Infantile Malnutrition: Changes in Body Composition During Rehabilitation
}

\author{
- George G. Graham ${ }^{[22]}$, Angel Cordano, Robert M. Blizzard and Donald B. Gheek \\ The Grace Department of Research, British American Hospital, Lima, Peru, \\ and the Children's Medical and Surgical Center, The Johns Hopkins Hospital, Baltimore, Maryland, USA
}

\section{Extract}

Total body water (TBW), intracellular (ICW) and extracellular (EGW) spaces, muscle mass and supporting tissue were measured in nine malnourished infants, 5-30 months of age, shortly after hospitalization, and then following 4-9 months of rehabilitation. Initially all infants had severe growth deficits, height age being 4-64\% (average $40 \%$ ) and weight age $0-40 \%$ (average $15.6 \%$ ) of chronologic age. TBW ranged from 63.5 to $89.3 \%$ of body weight and ECW ranged from 38.6 to $50.6 \%$ of TBW, suggesting marked losses of cell mass and body fat, with conservation of supporting tissues. Excretory levels of creatinine and hydroxyproline ranged from 31 to $86 \mathrm{mg} / 24 \mathrm{~h}$ and from 10.3 to $28.5 \mathrm{mg} / 24 \mathrm{~h}$, respectively. During rehabilitation all patients exhibited accelerated growth, height age becoming $28.6-69.1 \%$ (average $58.8 \%$ ) of chronologic age; most of the children became moderately obese. With the exception of one infant, who did not gain weight well despite satisfactory linear growth, excretion of creatinine increased $23-136 \%$ and excretion of hydroxyproline increased $45-360 \%$ over the initial values. TBW became $54.7-65 \%$ of body weight and ECW $41.8-55.9 \%$ of TBW. Proportionally smaller increases in metabolically active protoplasm, represented by ICW, were experienced in four infants under 11 months (average $25 \%$, than in four of five infants over 11 months of age (average $67.5 \%$ ); however; these four infants demonstrated proportionately greater gains in ECW (77 versus $36 \%$ ).

Determinations of blood sugar, growth hormone and insulin responses to arginine were made in five of these patients and in three additional infants. On admission, the levels of growth hormone in these infants were found to be elevated $(11.5-18 \mathrm{ng} / \mathrm{ml})$ and did not respond to arginine injection; determination of blood sugar also showed elevated levels $(119-182 \mathrm{mg} / 100 \mathrm{ml})$. One to three months later the response was usually normal. Insulin responses, initially and after partial rehabilitation, were almost invariably blunted, with only one child, at 50 days, showing a rise to $45 \mathrm{ng} / \mathrm{ml}$.

It is apparent that growth during recovery from malnutrition is neither a uniform process nor is it simply reinitiation of normal growth.

\section{Speculation}

The apparently normal production of growth hormone and the impaired insulin response, which was persistently demonstrated by these infants, along with the poor growth in cell mass of those under 11 months of age, suggest that gains in cell mass in the younger infant may be primarily dependent on insulin and not on growth hormone. Cartilage and other supporting tissues may continue to respond to growth hormone, despite fairly severe malnutrition. 
Introduction

Justifiable concern exists over the long-term effects of infantile malnutrition on the ultimate physical and mental development of survivors. Most studies document significant stunting in height, head size, and apparent intelligence $2-7$ years later $[5,8,12,17]$. The assumption is made, with reservations, that the apparent deficits result from severe malnutrition in infancy; observations have not been prolonged enough to allow predictions of adult size. Cross-sectional studies suggest that the deficits are permanent and not simply delays in maturation. In these studies, it is impossible to separate the effect of severe early malnutrition from that of chronic undernutrition in a hostile environment, to which nearly all of these children return, and to define genetic growth potential.

One study [7] indicated that a group of severely malnourished infants achieved the same size as their 'healthy' siblings, and the norm for the rural population from which they came. Children living in a community in which there is a high prevalence of malnutrition exist in an environment of malnutrition, and therefore, one cannot assume that any children escaping kwashiorkor were in fact either well nourished or growing at rates consistent with their optimal genetic potential. HANSEN [10] has documented the fact that siblings of malnourished infants grow poorly. In contrast, we have noted that a few children from families that have managed to work themselves out of the slums in which they had been living were still growing at an accelerated rate 5 years later, coming closer to the norms for children in developed countries [8].

Despite the inadequacies of such studies and with the support of experimental data in animals, there is general agreement that severe and prolonged malnutrition in early life must cause permanent deficits in stature, muscle mass, brain size and possibly in intelligence. We need to define more precisely the effects of severe malnutrition in infancy and early childhood, particularly reversibility or permanence. Having defined these, we need to know if it is possible to prevent or ameliorate the apparently inevitable after-effects.

Our knowledge of 'normal' growth patterns and regulation of normal growth is incomplete, particularly at the ages when most cases of malnutrition occur. This gap is slowly being filled [2]. Newer techniques of hormone assay, improved indirect measures of body composition, and direct analyses of biopsy tissue are supplementing the meager number of reliable total body analyses, which until recently constituted our entire knowledge of the changes in body composition that occur with age. Over a number of years, application of these techniques to the longitudinal study of the malnourished infant should increase our understanding of the normal course of events.

Although the techniques now employed are not applicable to large numbers of children, the measurements obtained are being related to common anthropometric and biochemical measurements. The results suggest that it is possible to make reasonably accurate estimates of body composition from these measurements. Others [16] have indicated that measurement of height and weight of malnourished infants does not predict the size of muscle mass, and that the amount of creatinine excreted in the urine was a more accurate indicator. Biopsies of muscle and liver [19] from malnourished and partially rehabilitated children gave some indication of cell size. Various investigators $[1,9$, 15] have reported the problems of hormonal adjustments to malnutrition, but different clinical and experimental methods have resulted in additional confusion.

We are involved in a longitudinal study of the ultimate growth of severely malnourished infants and small children admitted to the British American Hospital. All patients receive adequate diets during hospitalization and when in a convalescent unit; some stay 4 months, some remain for as long as 2 years. A few are discharged to a much improved home environment, but most return to the same circumstances from which they came, although at a less vulnerable age.

In a number of male infants the relation of hormonal mechanisms and growth was studied more intensely, both at the time of admission and at intervals during rehabilitation. In some of these infants and in a number of others, studies of body composition were made within the 1st month of admission, after disappearance of infection or edema, and again 4-9 months later, when rehabilitation was well under way, as indicated by gains in weight and height and by satisfactory nitrogen retentions. This study reports the changes in anthropometric measurements and changes in levels and percentages of total body water, extracellular water, intracellular water, excretion of creatinine, and excretion of hydroxyproline in nine infants. A companion publication [4] describes the changes in number, size and composition of muscle cells.

\section{Methods}

Nine male infants (M1-M9) were admitted to the hospital with clinical evidence of severe marasmus : loss of subcutaneous fat, severe muscle wasting, failure of linear growth, and very marked deficits in weight. In the two oldest patients, M5 and M6, symptoms of kwashiorkor were superimposed on that of marasmus. Patient M1 was hypoalbuminemic $(<3.0 \mathrm{~g} / 100 \mathrm{ml})$ on 
admission. In most of the nine infants, acute diarrhea and other infections had been present, including signs of kwashiorkor in M1, M5 and M6, but at the time of the initial study, all infections were controlled.

As in a previous report [8], heights and weights were converted to the corresponding age on the 50th percentile of a widely used growth curve for children in the United States [18]. Although this standard might not be realistic for Peruvian mestizo children, it serves as a familiar point of reference when the genetic growth potential is an unknown entity. This reference standard permits the expression of height and weight on the same scale, relating 'height age' and 'weight age' to chronologic age.

The methods used for determining the values of total body water, extracellular water, excretion of creatinine and hydroxyproline were the same as in previous studies of normal infants and children [2]. At the time of the initial study, all the infants were on a modified milk diet; at the time of the repeat study, all were on a casein diet or an all-vegetable protein diet. Arginine $(0.5 \mathrm{~g} / \mathrm{kg}$ of ideal body weight for height) was infused intravenously to measure responses in true blood glucose, plasma growth hormone $(\mathrm{GH})$ and immunoreactive insulin (IRI) [2].

\section{Results}

Brief clinical and dietary histories of the nine infants are available in the Appendix. Table I presents the data on age, 'height age', body weight, total body water, extracellular water and intracellular water (by difference) and amount of creatinine and hydroxyproline excreted during study periods 1 and 2 .

Table II lists the age of the infants during study 1 , the interval between studies 1 and 2, the advance in height age during this interval, and the percentage changes in body weight, total body water (TBW), extracellular water (ECW), intracellular water (ICW), excretion of creatine (C), and hydroxyproline (HOP). Increments in height age ( $\triangle \mathrm{HA})$ that equal or exceed the time interval ( $\triangle \mathrm{CA}$ ) can be interpreted in two ways: a genetic growth potential equal to or better than the 50th percentile of the U.S. standard (most unlikely), or accelerated 'catch-up' growth at a rate corresponding to the biologic rather than the actual age. Linear growth at a slower rate might be due to less genetic potential (at least partially true) or to altered growth potential. Table III shows the ages of the patients at the time of both studies, the levels of TBW when expressed as a percentage of body weight and the levels of EGW when expressed as a percentage of TBW.

Patient M1 grew in length at an accelerated rate and excreted increased amounts of HOP. Rates of increase in excretion of ICW and C exceeded those for body weight, TBW and EGW. The abnormally high percentages of body weight in relation to TBW and of TBW in relation to ECW in study period 1 returned to the values expected at his age (table III).

In patient M2, the linear growth was less than expected, despite increased excretion of HOP and C: only a small increase in ICW was evident. In study period 1 patient M2 had unusually high TBW levels, $89.3 \%$ of body weight; however, after 5 months this level returned to normal, $60.5 \%$ of body weight. ECW, when expressed as a percentage of TBW, remained relatively high.

Patient M3 had the longest interval between studies, 269 days; he grew at an accelerated rate in body length and showed a very large increase in excretion of HOP. His increases in excretion of ICW and $\mathrm{C}$, like patient M1, were proportionately greater than the increases of TBW and ECW, although ECW, as well as the gain in weight, was large. TBW, expressed as a percentage of body weight, returned toward normal levels, but ECW, expressed as a percentage of TBW, remained moderately elevated.

The linear growth of patient M4, despite weight gain to the point of visible obesity, was relatively slow. After study period 2 growth proceeded at an even slower rate, suggesting a very small genetic stature or a seriously compromised growth potential. Increases in excretion of HOP and in ECW were greater than increases in excretion of C; they exceeded the very modest gain in ICW, which was one of the poorest in the group. TBW, expressed as a percentage of body weight, fell from a high value of $79.7 \%$ to an abnormally low value, $54.7 \%$, while ECW increased to a high percentage, $51.4 \%$ of TBW.

Patient M5 demonstrated satisfactory linear growth after a lag period, a very large gain in excretion of HOP, a smaller but still impressive gain in excretion of $\mathrm{C}$, and relatively modest gains in weight, ECW and ICW. TBW, expressed as a percentage of body weight, was close to normal for age in both studies, and ECW, expressed as a percentage of TBW, did not change.

Patient M6 differed strikingly from all the others in that, despite satisfactory linear growth, he did not gain weight during the last 3 months of the study and actually demonstrated a fall in excretion of HOP and no gain in excretion of C. TBW levels, both in absolute terms and expressed as percentages of body weight, changed relatively little, as did ECW, in absolute or relative terms. If it were not for the good gain in length, it might be said that he grew very little and that his body composition did not change.

Patient M7 grew well in length, had modest increases in excretion of HOP and $\mathrm{C}$ and demonstrated an important gain in ICW. TBW fell to a low value of 
$55.3 \%$ of body weight and ECW to a normal value of $41.8 \%$ of TBW.

Patient M8 grew relatively well in height, made impressive gains in excretion of HOP, and showed a particularly large increase in ECW, both in absolute terms and when expressed as a percentage of TBW.
His gains in excretion of ICW and $\mathrm{G}$ were quite modest. TBW levels fell to below $60 \%$ of body weight in study 2.

Patient M9 showed important progress in all variables of growth, but the percentage increments in ECW and HOP exceeded those in ICW and C.

Table I. Chronologic age (CA), height age (HA), body weight (body wt), total body water (TBW), extracellular water (ECW), intracellular water (ICW), excretion of creatinine (C), and excretion of hydroxyproline (HOP) in nine malnourished infants shortly after admission (study period 1) and 4-9 months later (study period 2)

\begin{tabular}{lccccccccc}
\hline $\begin{array}{l}\text { Patient. } \\
\text { no. }\end{array}$ & $\begin{array}{c}\text { Study } \\
\text { period }\end{array}$ & $\begin{array}{c}\text { GA, } \\
\text { months }\end{array}$ & $\begin{array}{c}\text { HA, } \\
\text { months }\end{array}$ & $\begin{array}{c}\text { Body wt, } \\
\mathrm{kg}\end{array}$ & $\begin{array}{c}\text { TBW, } \\
\text { liter }\end{array}$ & $\begin{array}{c}\text { ECW, } \\
\text { liter }\end{array}$ & $\begin{array}{c}\text { ICW, } \\
\text { liter }\end{array}$ & $\begin{array}{c}\text { G, } \\
\mathrm{mg} / 24 \mathrm{~h}\end{array}$ & $\begin{array}{c}\text { HOP, } \\
\mathrm{mg} / 24 \mathrm{~h}\end{array}$ \\
\hline M1 & 1 & 13 & 4.5 & 4.94 & 3.54 & 1.79 & 1.75 & 33 & 13.4 \\
& 2 & 17.5 & 10.5 & 9.00 & 5.62 & 2.35 & 3.27 & 71 & 45.3 \\
M2 & 1 & 8 & 4 & 4.30 & 3.84 & 1.78 & 2.06 & 31 & 10.9 \\
& 2 & 13 & 7.5 & 7.68 & 4.66 & 2.20 & 2.46 & 66 & 40.9 \\
M3 & 1 & 16 & 7.5 & 5.11 & 3.98 & 1.93 & 2.05 & 50 & 10.3 \\
& 2 & 25 & 16 & 11.31 & 7.17 & 3.26 & 3.91 & 118 & 47.4 \\
M4 & 1 & 6 & 0.25 & 3.25 & 2.59 & 1.00 & 1.59 & 32 & 18.2 \\
& 2 & 10.5 & 3 & 7.01 & 3.83 & 1.97 & 1.86 & 57 & 44.5 \\
M5 & 1 & 30.5 & 18.5 & 9.33 & 5.93 & 2.84 & 3.09 & 85 & 17.3 \\
& 2 & 34.5 & 23 & 12.45 & 7.60 & 3.50 & 4.10 & 148 & 62.9 \\
M6 & 1 & 22 & 14 & 8.43 & 5.36 & 2.49 & 2.87 & 86 & 28.5 \\
& 2 & 27.5 & 19 & 10.03 & 6.52 & 3.22 & 3.30 & 89 & 22.6 \\
M7 & 1 & 11.5 & 5.5 & 5.95 & 3.80 & 1.85 & 1.95 & 60 & 19.3 \\
& 2 & 16 & 11 & 9.63 & 5.33 & 2.23 & 3.10 & 74 & 28.0 \\
M8 & 1 & 10.5 & 5 & 5.95 & 3.67 & 1.44 & 2.23 & 53 & 18.2 \\
& 2 & 17 & 10.5 & 9.74 & 5.65 & 2.96 & 2.69 & 67 & 41.8 \\
M9 & 1 & 5 & 0.5 & 3.41 & 2.88 & 1.43 & 1.45 & 31 & 13.5 \\
& 2 & 9.5 & 5 & 7.69 & 4.69 & 2.62 & 2.07 & 51 & 28.0 \\
\hline
\end{tabular}

Table II. Chronologic age (CA) at the time of study 1 , interval between studies ( $\triangle \mathrm{CA}$ ), advance in height age ( $\Delta \mathrm{HA})$, and percentage changes in body weight ( $\Delta$ Body wt), total body water $(\Delta \mathrm{TBW})$, extracellular water $(\Delta \mathrm{ECW})$, intracellular water $(\Delta \mathrm{ICW})$, excretion of creatinine $(\Delta \mathrm{G})$, and excretion of hydroxyproline $(\Delta \mathrm{HOP})$ in nine malnourished infants

\begin{tabular}{|c|c|c|c|c|c|c|c|c|c|}
\hline $\begin{array}{l}\text { Patient } \\
\text { no. }\end{array}$ & $\begin{array}{c}\text { CA, } \\
\text { months }\end{array}$ & $\begin{array}{l}\triangle \mathrm{CA}, \\
\text { months }\end{array}$ & $\begin{array}{l}\triangle \mathrm{HA}, \\
\text { months }\end{array}$ & $\begin{array}{c}\Delta \text { Body wt, } \Delta \\
\%\end{array}$ & $\begin{array}{l}\text { TBW, } \\
\%\end{array}$ & $\begin{array}{c}\Delta \mathrm{ECW} \\
\%\end{array}$ & $\underset{\%}{\Delta \mathrm{ICW}}$ & $\begin{array}{c}\Delta \mathrm{C}, \\
\%\end{array}$ & $\begin{array}{c}\Delta \mathrm{HOP} \\
\%\end{array}$ \\
\hline M1 & 13 & 4.5 & 6 & 82 & 59 & 31 & 87 & 115 & 238 \\
\hline M2 & 8 & 5 & 3.5 & 78 & 21 & 24 & 19 & 113 & 275 \\
\hline M3 & 16 & 9 & 8.5 & 121 & 80 & 69 & 91 & 136 & 360 \\
\hline M4 & 6 & 4.5 & 2.75 & 115 & 48 & 97 & 17 & 78 & 144 \\
\hline M5 & 30.5 & 4 & 4.5 & 33 & 28 & 23 & 33 & 74 & 264 \\
\hline M6 & 22 & 5.5 & 5 & 19 & 22 & 30 & 15 & 3 & -21 \\
\hline M7 & 11.5 & 4.5 & 5.5 & 62 & 40 & 21 & 59 & 23 & 45 \\
\hline M8 & 10.5 & 6.5 & 5.5 & 80 & 54 & 105 & 21 & 26 & 129 \\
\hline M9 & 5 & 4.5 & 4.5 & 126 & 63 & 83 & 43 & 65 & 107 \\
\hline
\end{tabular}


Table III. Total body water (TBW) as a percentage of body weight (body wt), and extracellular water (ECW) as percentage of TBW shortly after admission and 4-9 months later in nine malnourished infants. Age in months (CA) at the time of study 1 and 2

\begin{tabular}{lcclc}
\hline $\begin{array}{l}\text { Study } \\
\text { period }\end{array}$ & $\begin{array}{c}\text { Patient } \\
\text { no. }\end{array}$ & $\begin{array}{c}\text { CA, } \\
\text { month }\end{array}$ & $\begin{array}{c}\text { TBW, } \\
\text { \% bodywt }\end{array}$ & $\begin{array}{c}\text { ECW, } \\
\% \text { TBW }\end{array}$ \\
\hline 1 & M1 & 13 & 70 & 50.6 \\
2 & & 17.5 & 62.4 & 41.8 \\
1 & M2 & 8 & 89.3 & 46.3 \\
2 & & 13 & 60.5 & 47.2 \\
1 & M3 & 16 & 78 & 48.5 \\
2 & & 25 & 63.5 & 45.5 \\
1 & M4 & 6 & 79.7 & 38.6 \\
2 & & 10.5 & 54.7 & 51.4 \\
1 & M5 & 30.5 & 63.6 & 47.9 \\
2 & & 34.5 & 60.8 & 46.1 \\
1 & M6 & 22 & 63.6 & 46.5 \\
2 & & 27.5 & 65 & 49.4 \\
1 & M7 & 11.5 & 63.5 & 48.7 \\
2 & & 16 & 55.3 & 41.8 \\
1 & M8 & 10.5 & 68 & 39.2 \\
2 & & 17 & 58 & 52.4 \\
1 & M9 & 5 & 84.5 & 49.6 \\
2 & & 9.5 & 61 & 55.9 \\
\hline
\end{tabular}

\section{Growth Hormone and Insulin}

Table IV shows the concentrations of blood glucose, plasma growth hormone, and plasma immunoreactive insulin after infusion of arginine in five of nine infants originally studied and in three other malnourished male infants. One infant was studied on day 50 of hospitalization and two others, as in the case of patient M9, shortly after admission and prior to oral feeding.

The sustained hyperglycemia of patient M9 during the entire $2-\mathrm{h}$ study is notable. He had reputedly received a dilute milk feeding at home $3 \mathrm{~h}$ before the arginine infusion. His 'fasting' GH level was elevated and did not respond further; there was no increase in IRI levels. The following day, after regular milk feedings were begun, fasting blood glucose value was $112 \mathrm{mg} / 100 \mathrm{ml}$; on days 3 and 4 it was 96 and $97 \mathrm{mg} /$ $100 \mathrm{ml}$, respectively.

The additional infants studied on admission, patient 203 (age 21 months) and patient 204 (age 11 months), were fasted for $4 \mathrm{~h}$ in the hospital prior to infusion of arginine. Patient 203 also had a sustained hyperglycemia, persistently elevated and unresponsive GH concentrations, and no IRI response. Levels of blood glucose were followed closely during the next $24 \mathrm{~h}$ and remained elevated until intravenous infusion of a com-

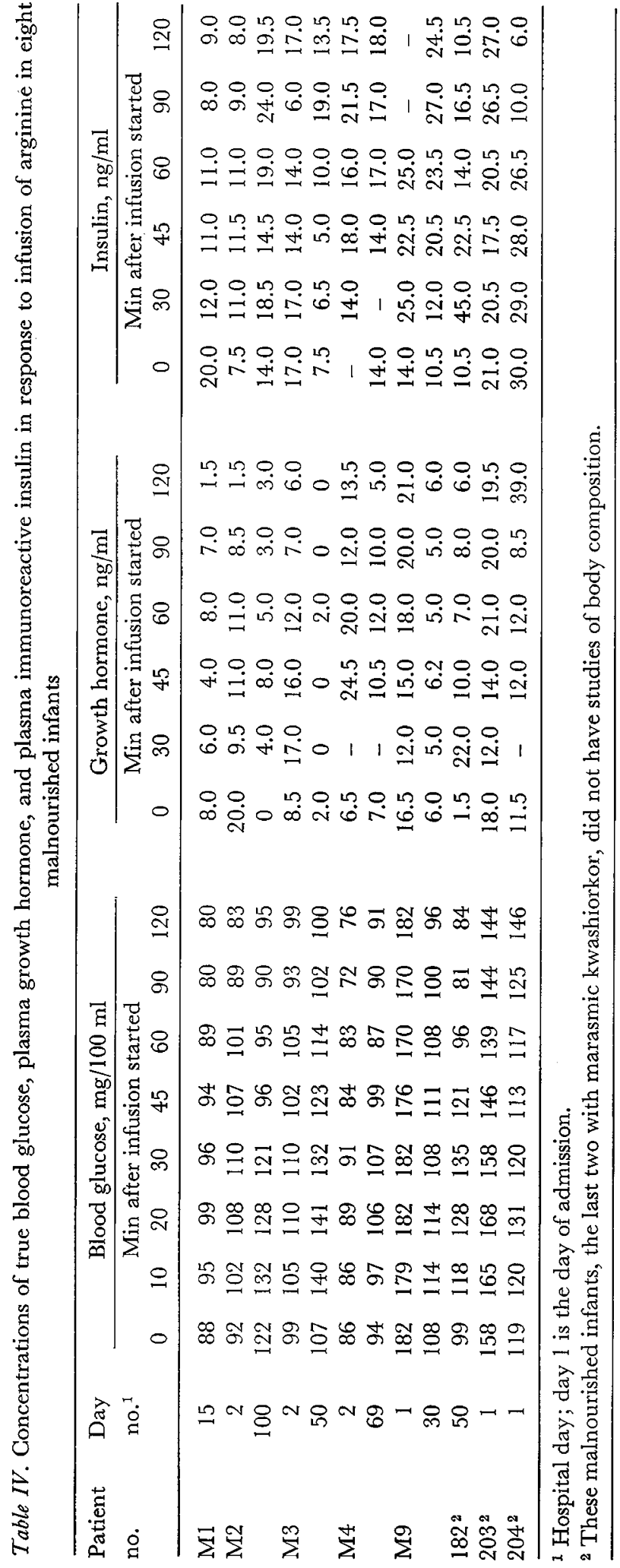


plete amino acid mixture. The concentration fell to normal levels after the infusion was completed, but rose again until milk feedings were given. Patient 204 had a more modest hyperglycemia, persistently elevated $\mathrm{GH}$ and no IRI response.

The three patients studied on day 2 had normal blood glucose levels and GH responses, but again no IRI response. One patient studied on day 15 showed no change in GH and IRI concentrations. Patient M9, restudied on day 30 , demonstrated the expected blood glucose levels, but had no GH response and an insignificant IRI response to the arginine infusion. Ratient $\mathrm{M} 3$, restudied on day 50 , had no GH or IRI responses, despite a marked increase in the blood glucose level after the infusion.

Patient 182, 22 months of age, was studied on day 50; he showed a satisfactory GH response and a significant but modest elevation in plasma IRI levels, the only such elevation in this series. Patients M2 and M4, restudied on days 100 and 69, respectively, had normal GH but flat IRI responses.

\section{Discussion}

Linear growth results primarily from proliferation of cartilage cells in the epiphyseal areas of the long bones. Excretion of hydroxyproline is generally considered an index of collagen turnover, including epiphyseal growth, while excretion of creatinine on creatinecreatinine-free diets is accepted as a measure of muscle mass [6]. Intracellular water is the difference between the distribution of deuterium oxide and the corrected bromide space. Since the ratio of cell water to cell protein is constant except in the immediate postnatal period, this variable is a measure of cell mass [3], representing mainly muscle cells and visceral cells. Hence, intracellular water is a good measure of the metabolically active protoplasm.

In the newborn about $75 \%$ of the body weight is water. By 4 months of age this percentage has decreased to approximately $60 \%$ [6]. Figures below this level generally indicate excessive body fat. Values of around $70 \%$ are generally found again in the fat-free mature individual. TBW, as a percentage of body weight, falls during the 1 st year of life, partially at the expense of ECW, which at the end of the 1st year constitutes approximately $40 \%$ of TBW [6].

The variability in the condition of malnourished infants and the complicating infections that are usually present require caution in interpreting all findings. Initial studies were delayed until we felt certain that infection had been controlled and that the acute changes resulting from infection and diarrhea had been corrected. Manifestations of kwashiorkor, added to those of chronic undernutrition and a marked protein/ calorie imbalance, distort the basic alterations in body composition. Even so, there are important differences between cases, particularly chronologic age, and the timing, duration and severity of undernutrition, all of which must affect the rate and nature of growth during recovery. All the infants studied were males. Although at their ages, sex differences are unlikely to be important, they must still be considered.

Most of the infants displayed accelerated rates of linear growth during recovery; two of the youngest patients, M2 and M4, made the poorest gains. Nearly all had dramatic increases in collagen turnover; patient M6, despite good linear growth, showed poor weight gain and a decrease in excretion of HOP; patient M7 had only a moderate increase. In eight of the nine infants, patient M6 excepted, the percentage increase in excretion of HOP largely exceeded that in excretion of creatinine, suggesting that collagen increased at a faster rate than did muscle protein.

Initially, body water was $68-89.3 \%$ of body weight in patients M1, M2, M3, M4, M8 and M9, suggesting large deficits in body fat. The highest values were in the three youngest patients. The three lowest values, close to the expected $60 \%$ of their ages, were in the two who presented with kwashiorkor, patients M5 and M6 (also the two oldest), and in patient M7. The values after partial rehabilitation, all close to $60 \%$, suggested important increases in body fat; this was probably excessive in at least two infants, patients M4 and M7.

Figure 1 illustrates the relation of TBW and ICW levels to body length in these nine infants, compared with curves derived from normal infants in the United States [2]. TBW levels were quite low initially, as were ICW levels. ECW levels were not plotted, but would have appeared normal in almost every instance. After rehabilitation, TBW values were nearly always normal for length, ICW levels generally were still low, and ECW levels remained normal or were now increased. In the four youngest subjects ECW values had increased at a considerably greater rate than had cell mass (table II), becoming $47.2-55.9 \%$ of TBW (table III). Even patient M6, who had gained no weight during the last 3 months of rehabilitation, had no increase in muscle mass and had a decrease in collagen turnover, showed a proportionately greater increase in ECW.

Gains in muscle mass (creatinine excretion) were relatively small in patient M7 (despite good gain in ICW) and in patient M8 and much larger in the remaining six infants. Relative to gains in body weight and body water, the gains in cell mass (ICW) were smallest in the four youngest patients (M2, M4, M8 and M9) and most impressive in four of the five oldest patients (M1, M3, M5 and M7). 
Malnutrition in the experimental animal affects the connective tissues of the body much less than it does the metabolically active protoplasm [11]. Collagen accounts for a much higher percentage of body protein in the severely malnourished infant than in the normal

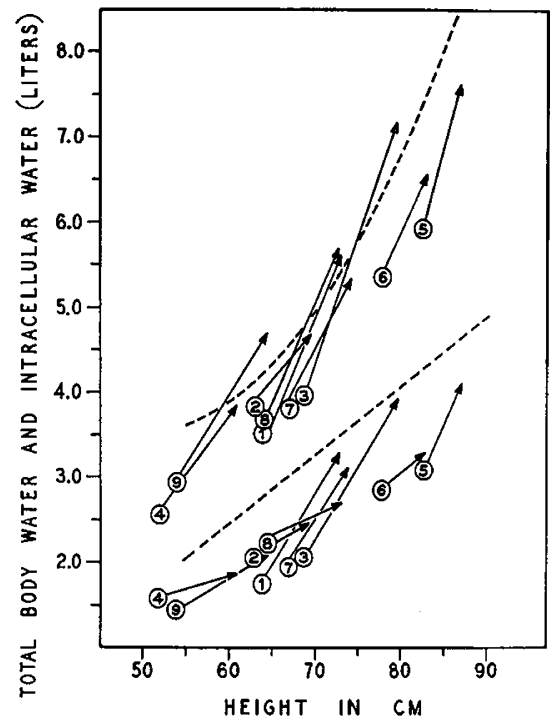

Fig. 1. Evolution of total body water (upper part) and intracellular water (lower part) of nine malnourished infants as a function of body length (height). The broken lines were derived from values for normal infants in the United States (see text).

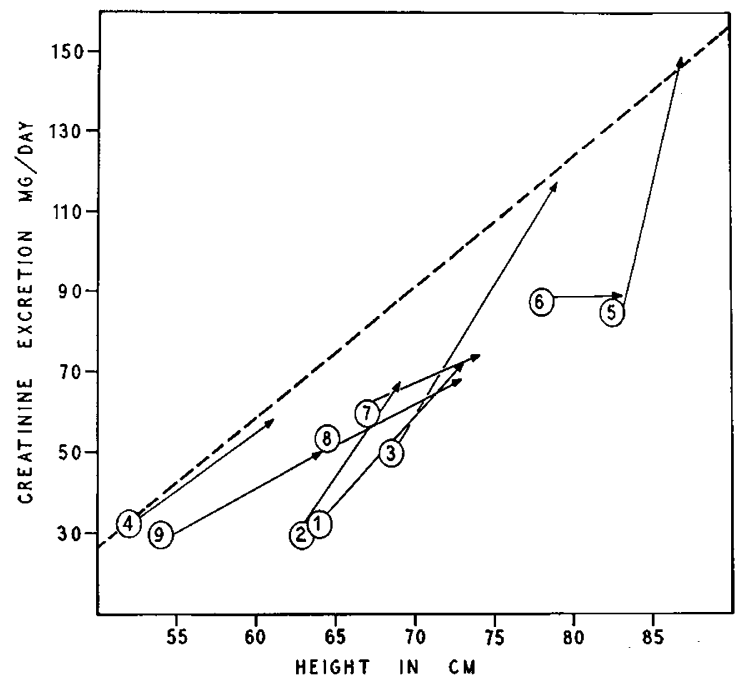

Fig. 2. Evolution of muscle mass (excretion of creatinine) in nine malnourished infants as a function of body length (height). The broken line was derived from values for normal infants in the United States. infant [14]. The initial body composition of our patients with an ECW value that was normal for height, a much reduced cell mass, and a muscle mass that was low for height (fig. 2), suggested a great loss of metabolically active protoplasm and conservation of supporting tissues. In the infants under 1 year of age the body composition more nearly resembled that of the newborn infant, and in some respects, that of the premature. The very high percentage of body weight represented by TBW and the high percentage of body water represented by ECW in most of the infants studied suggest that, beyond the loss of linear growth, there had been an almost complete loss of body fat and very large losses in visceral and muscle cell protein, confirming the clinical and pathological appearance of the marasmic infant. In the initial study only three infants had TBW contents, expressed as percentage of body weight, that were close to the normal $60 \%$ for their age, suggesting some conservation of body fat. Two of these infants had presented with kwashiorkor, where assumed higher calorie intakes assure some degree of conservation of body fat.

The nature of the weight gain during rehabilitation is of great concern. All nine infants grew in length, and all but one had increased excretion of HOP, indicating collagen turnover and suggesting that the same supporting tissues that were least affected by undernutrition increased most readily when an adequate diet was again provided. Four of the infants, 11.5-30.5 months of age when first studied, had proportionately the greatest gains in cell mass, and four others, 5-10.5 months of age, had proportionately greater gains in extracellular water and probably in body fat as well. One infant, 22 months of age, gained well in length but poorly in weight, cell mass, muscle mass, extracellular water, collagen and most probably body fat.

Although age-related differences in the nature of growth were not always apparent, the younger malnourished infants appeared to be less efficient than the older ones in adding to their metabolically active cell mass during recovery. In this respect, their growth resembled that of the normal infant in the first 4 months of life, while that of the older ones was more characteristic of the second semester of extrauterine life in the normal infant [6], suggesting that their 'biologic age' corresponded in many respects to their 'height age'. The changes in number, size and composition of muscle cells also indicated age-related differences [4]. The one child who grew only in body length also increased his muscle cell number, while further reducing the size of his initially small muscle cells.

Although the results of the growth hormone and insulin determinations are suggestive, they require confirmation and extension. Pimstone et al. [15] have previously documented high fasting $\mathrm{GH}$ levels in 
marasmus and marasmic kwashiorkor, as well as their return to normal after feeding protein. The finding of sustained hyperglycemia in three infants studied before the initiation of feedings was unexpected, although a review of our records had shown that hyperglycemia in the initial blood samples drawn before any feeding is not unusual. The normal GH responses to arginine in most infants after the 1st day of infusion suggest an intact pituitary function. Although poor $\mathrm{GH}$ responses to arginine and other stimuli are not uncommon in normal infants [13], we encountered them more often than expected. The sample, however, is too small for valid conclusions. Poor insulin responses have already been documented in malnourished infants [9]. The persistence of this finding well into the rehabilitation period in nearly all cases may partially explain the nature of growth during recovery and requires confirmation and extension.

It is apparent from these limited studies that the nature of growth during recovery differs in many respects from that of normal growth and that some tissues suffer less and recover more promptly than others. Using a different technique to estimate body fat, STANDARD et al. [16] also concluded that fat increased at a faster rate than did muscle mass during rehabilitation. The present observations do not provide information about the course of events in the central nervous system.

\section{Summary}

Total body water, extracellular water, excretion of creatinine and excretion of hydroxyproline were measured in nine severely malnourished infants, 5-30 months of age, shortly after admission to the hospital and after 4-9 months of rehabilitation. Initially, the deficits in body weight were considerably larger than those in height, mostly at the expense of body fat and cellular mass, both of muscle and of viscera. Linear growth and gains in body fat and supporting tissues were generally at an accelerated rate, corresponding to the 'height age'. The gains in cell mass, including muscle mass, were proportionately much greater in infants past the age of 11 months, and smaller in those below this age, who had more impressive gains in extracellular water, fat and collagen. One infant, 22 months of age on admission, had satisfactory linear growth but poor weight gain and only modest increases in extracellular water and cell mass; muscle mass and collagen turnover did not increase.

Determinations of growth hormone and insulin responses to arginine infusion in five of these infants and three additional ones suggested that growth hormone responses were normal but that insulin responses were considerably blunted, even after partial rehabilitation.

\section{References and Notes}

1. Castellanos, H. and Arroyave, G.: Role of the adrenal cortical system in the response of children to severe protein malnutrition. Amer.J. clin. Nutr. 9: 186 (1961).

2. CHeEk, D. B.: Human growth: body composition, cell growth, energy, and intelligence (Lea and Febiger, Philadelphia 1968).

3. Gheek, D. B. and Graystone, J. E.: Intracellular and extracellular volume (and sodium), and exchangeable chloride in children; in: D. B. GHEEK: Human growth: Body composition, cell growth, energy, and intelligence, p. 150 (Lea and Febiger, Philadelphia 1968).

4. Cheer, D. B.; Hill, D. E.; Cordano, A. and GraHAM, G.G.: Infantile malnutrition: changes in muscle cell size and number. (To be published.)

5. Gravioto, J. and DeLicardie, E.R.: Intersensory development of school-age children; in: N.S. Scrimshaw and J. E. Gordon: Malnutrition, learning, and behavior, p.252 (M.I.T. Presse, Cambridge 1968)

6. Fomon, S.J.: Growth of body components; in: Infant nutrition, p. 25 (Saunders, Philadelphia 1967).

7. Garrow,J.S.; Pike, M. D. : The long-term prognosis of severe infantile malnutrition. Lancet $i$ : 1 (1967).

8. Graham, G. G.: The later growth of malnourished infants; effects of age, severity, and subsequent diet; in: R. A. MaCANCE and E.M.WIddowson: Calorie deficiencies and protein deficiencies, p. 301 (Churchill, London 1968).

9. HADDEN, D. R. and BEIF, M. D.: Glucose, free fatty acid, and insulin interrelations in kwashiorkor and marasmus. Lancet $i i: 589$ (1967).

10. HANSEN, J.D. L.: Body composition and appraisal of nutriture, part II; in: J. Brozer: Human body composition: approaches and applications, p. 255. Symp. Soc. Study of Human Biology, vol. VII (Pergamon, Oxford 1965).

11. Mendes, C.B. and Waterlow, J.C.: The effect of a low protein diet, and of refeeding, on the composition of liver and muscle in the weanling rat. Brit.J. Nutr. 12: 74 (1958).

12. MönckeberG, F.: Effect of early marasmic malnutrition on subsequent physical and psychological development; in: N.S. Scrimshaw and J.E.GorDON: Malnutrition, learning, and behavior, p. 269 (M.I.T. Press, Cambridge 1968).

13. Penny, R.; Davis, W. and Blizzard, R.M.: Provocative stimuli for growth hormone release in adults and children. (To be published.)

14. Picou, D.; Alleyne, G.A.O. and Seakins, A.: Hydroxyproline and creatinine excretion in infantile protein malnutrition. Clin. Sci. 29: 517 (1965). 
15. Pimstone, G. L.; Barbezat, G.; Hansen, J.D. L. and Murray, P.: Studies on growth hormone secretion in protein-calorie malnutrition. Amer.J. clin. Nutr. 21: 482 (1968).

16. Standard, K.L.; Wills, V.G. and Waterlow, J. C.: Indirect indicators of muscle mass in malnourished infants. Amer. J. clin. Nutr.7: 271 (1959).

17. Sтосн, M.B. and Sмхтне, P.M.: The effect of undernutrition during infancy on subsequent brain growth and intellectual development. Sth. afr. med. J. 41: 1027 (1967).

18. Stuart, H. C.: in: F.H.HARvie: Pediatric methods and standards, p.21 (Lea and Febiger, Philadelphia 1958).

19. WATERLOW, J. G.: The protein content of liver and muscle as a measure of protein deficiency in human subjects. West Indian med. J. 5: 167 (1956).

20. The authors gratefully acknowledge the assistance of Drs. William C. Maclean, Jr., Gladys AceVEDo and Julio NAKASHima in carrying out these studies.

21. Supported by National Institutes of Health Grants nos. AM-09980-04, HD-00126-06 and HD-0185204.

22. Requests for reprints should be addressed to: George G. Graham, M.D., Department of Internal Health, The Johns Hopkins University, School of Hygiene and Public Health, 615 North Wolfe Street, Baltimore, Maryland 21205 (USA).

\section{Appendix}

\section{Individual Clinical and Dietary Histories}

Patient M1 was admitted at 12.5 months of age, length $63.7 \mathrm{~cm}$ (normal for 4.5 months), weight $4.53 \mathrm{~kg}$ (normal for 1.25 months), and having a serum albumin concentration of 3.65 , which on hydration fell to $2.72 \mathrm{~g} / 100 \mathrm{ml}$, when edema became apparent. He was maintained by the intravenous route until day 5 , when modified cow's milk formula was started. On day 15 , the level of serum albumin had risen to $3.21 \mathrm{~g} / 100 \mathrm{ml}$ and he was receiving $3.0 \mathrm{~g}$ protein and $100 \mathrm{kcal} / \mathrm{kg}$ body weight daily.

By the end of week 3, he was receiving $3.0 \mathrm{~g}$ protein and $125 \mathrm{kcal} / \mathrm{kg} / 24 \mathrm{~h}$; he was beginning to gain but apparent nitrogen retention was still low, approximately $11 \%$ of intake, or $55 \mathrm{mg} / \mathrm{kg} / 24 \mathrm{~h}$. Deuterium and bromide spaces, and excretions of creatinine and hydroxyproline were measured and biopsies of muscle and fat were obtained. Intake was gradually increased to $175 \mathrm{kcal} / \mathrm{kg} / 24 \mathrm{~h}$ and by day 80 he weighed $7.75 \mathrm{~kg}$. Over the next 22 days, intake was decreased to $2.0 \mathrm{~g}$ protein and $100 \mathrm{kcal} / \mathrm{kg} / 24 \mathrm{~h}$, enough to maintain steady weight gain and serum albumin concentrations above $4.0 \mathrm{~g} / 100 \mathrm{ml}$. During the next 11 days apparent nitrogen retention was $20 \%$ of intake, or $65 \mathrm{mg} / \mathrm{kg} /$ $24 \mathrm{~h}$. During the succeeding 33 days, until day 145, dietary protein was a blend of wheat and soy flours; this dietary mixture maintained approximately the same rates of weight gain and nitrogen retention. Casein was then made the source of protein and nitrogen retention increased to $25 \%$ of intake $(80 \mathrm{mg} / \mathrm{kg} / 24 \mathrm{~h})$; when height and weight ages were very similar, although only $50 \%$ of chronologic age, studies of body composition were repeated.

Patient M2 was admitted at 7.5 months of age; length $63 \mathrm{~cm}$ ( 4 months), weight $4.0 \mathrm{~kg}$ (0.5 month), serum albumin level $4.13 \mathrm{~g} / 100 \mathrm{ml}$. He immediately received small amounts of modified milk. By the end of week 3 he was receiving $3.0 \mathrm{~g}$ protein and $125 \mathrm{kcal} /{ }^{\prime}$ $\mathrm{kg} / 24 \mathrm{~h}$; he started to gain weight although nitrogen absorption was poor ( $58 \%$ of intake), apparent retention almost nil; the first study of body composition was made. Shortly thereafter protein intake was increased to $4.0 \mathrm{~g}$, and the calorie intake varied between 100 and $150 \mathrm{kcal} / \mathrm{kg} / 24 \mathrm{~h}$. Absorption and retention of nitrogen gradually improved and steady weight gain was established. On day 100 he weighed $6.0 \mathrm{~kg}$, was receiving $2.0 \mathrm{~g}$ protein and $125 \mathrm{kcal} / \mathrm{kg} / 24 \mathrm{~h}$, nitrogen absorption was $90 \%$ and retention $25-30 \%$ of intake $(80-100 \mathrm{mg} /$ $\mathrm{kg} / 24 \mathrm{~h}$ ).

On day 111 the source of protein was changed to a high protein wheat flour enriched with lysine. Weight gains $(3-4 \mathrm{~g} / \mathrm{kg} / 24 \mathrm{~h}$ ) and nitrogen retentions (80-140 $\mathrm{mg} / \mathrm{kg} / 24 \mathrm{~h}$ ) were consistently satisfactory and on day 160 body composition studies were repeated when weight age, though much improved, still lagged behind height age.

Patient M3 was 16 months old; height age 7.5 months $(68.3 \mathrm{~cm})$, weight age 2 months $(5.44 \mathrm{~kg})$, serum albumin concentration $3.58 \mathrm{~g} / 100 \mathrm{ml}$ on admission. Milk was given at once and by day 8 he was receiving $2.5 \mathrm{~g}$ protein and $100 \mathrm{kcal} / \mathrm{kg} / 24 \mathrm{~h}$; there had been a weight loss of $300 \mathrm{~g}$, nitrogen retention was practically nil despite normal absorption, and the first study of body composition was made. Calorie intake was increased to $125 \mathrm{kcal} / \mathrm{kg} / 24 \mathrm{~h}$, steady weight gain established, and nitrogen retention improved to about $25 \%$ of intake, or $80 \mathrm{mg} / \mathrm{kg} / 24 \mathrm{~h}$. On day 50 the source of protein was changed to lysine-enriched wheat flour, which was continued until day 197. He continued to gain rapidly $(4-6 \mathrm{~g} / \mathrm{kg} / 24 \mathrm{~h})$, and nitrogen retentions improved to $30-40 \%$ of intake $(90-130 \mathrm{mg} / \mathrm{kg} / 24 \mathrm{~h}$ ). He was placed on a varied diet and continued to grow at an accelerated rate until day 270 when he was placed on a casein diet yielding $2 \mathrm{~g}$ protein and $100 \mathrm{kcal} / \mathrm{kg} /$ $24 \mathrm{~h}$. Nitrogen retentions were satisfactory and on day 277 the study of body composition was repeated when 
weight age significantly exceeded height age and he was visibly obese.

Patient M4 was chronologically 5.5 months old; height age 0.25 month $(51.7 \mathrm{~cm})$, weight age newborn $(2.95 \mathrm{~kg})$, serum albumin concentration $4.01 \mathrm{~g} / 100 \mathrm{ml}$ on admission. Birth weight, crudely determined, had been just under $3 \mathrm{~kg}$, so it is likely that this infant, artificially fed a totally inadequate diet since birth, had grown next to nothing prior to his admission. He was given modified milk and by day 15 was receiving $3.0 \mathrm{~g}$ protein and $150 \mathrm{kcal} / \mathrm{kg} / 24 \mathrm{~g}$, gaining weight steadily, and retaining nitrogen well, $25-40 \%$ of intake, $125-200 \mathrm{mg} / \mathrm{kg} / 24 \mathrm{~h}$. The first study of body composition was carried out. He weighed $4.09 \mathrm{~kg}$ and measured $54.3 \mathrm{~cm}$ on day 69 .

On day 86 protein intake was reduced to $2.5 \mathrm{~g} / \mathrm{kg} /$ $24 \mathrm{~h}$. He continued to gain well and to retain $25-40 \%$ of nitrogen intake, $100-160 \mathrm{mg} / \mathrm{kg} / 24 \mathrm{~h}$. On day 110 dietary protein was changed to a blend of wheat and soy flours; weight gain and nitrogen retention continued at similar rates and on day 148 , when he weighed $7.0 \mathrm{~kg}$, measured $60.6 \mathrm{~cm}$, and was moderately obese, study of body composition was repeated.

Patient M5 was chronologically 29.5 months, height age 17.5 months $(81 \mathrm{~cm})$, weight age 8 months $(8.56$ $\mathrm{kg}$ ), and had a serum albumin concentration of $1.06 \mathrm{~g} /$ $100 \mathrm{ml}$ on admission, with manifestations of marasmic kwashiorkor. Milk feedings were begun at once and edema disappeared by day 12 . On day 25 he was receiving $2 \mathrm{~g}$ protein and $125 \mathrm{kcal} / \mathrm{kg} / 24 \mathrm{~h}$, serum albumin concentration was $3.3 \mathrm{~g} / 100 \mathrm{ml}$, he was beginning to gain weight, and he was retaining $27 \%$ of ingested nitrogen, $88 \mathrm{mg} / \mathrm{kg} / 24 \mathrm{~h}$. The first study of body composition was made. By day 68 , intake had been reduced to $100 \mathrm{kcal} / \mathrm{kg} / 24 \mathrm{~h}$, and the source of protein was changed to the wheat-soy blend. He continued to gain rapidly $(2-3 \mathrm{~g} / \mathrm{kg} / 24 \mathrm{~h})$ and to retain nitrogen satisfactorily $(40-70 \mathrm{mg} / \mathrm{kg} / 24 \mathrm{~h}$ ), and on day 107 was placed on a varied diet which yielded approximately $3.0 \mathrm{~g}$ protein and $100 \mathrm{kcal} / \mathrm{kg} / 24 \mathrm{~h}$. On day 153 , when he measured $86.7 \mathrm{~cm}$, weighed $12.4 \mathrm{~kg}$ and was on a casein diet, a second study of body composition was made. Weight for height was now approximately normal.

Patient M6 was admitted when he was 21 months of age; his height age was 13 months $(76.3 \mathrm{~cm})$, weight age 8.5 months $(8.85 \mathrm{~kg})$, and his serum albumin concentration was $2.13 \mathrm{~g} / 100 \mathrm{ml}$. He had manifestations of marasmic kwashiorkor. Milk was begun at once and by day 8 edema was no longer apparent. On day 28 serum albumin concentration was $3.41 \mathrm{~g} / 100 \mathrm{ml}$, weight was up to $8.31 \mathrm{~kg}$ (from a low of 7.68), and he was receiving $2.0 \mathrm{~g}$ protein and $125 \mathrm{kcal} / \mathrm{kg} / 24 \mathrm{~h}$. Nitrogen retention was approximately $100 \mathrm{mg} / \mathrm{kg} / 24 \mathrm{~h}$ ( $30 \%$ of intake), and the first study of body composition was made. By day 59, serum albumin levels were above $4.0 \mathrm{~g}$, he weighed $9.5 \mathrm{~kg}$, and the source of protein was changed to sweet whey enriched with soy flour at levels of $2.0 \mathrm{~g}$ protein and $100 \mathrm{kcal} / \mathrm{kg} / 24 \mathrm{~h}$. He gained weight $(2-3 \mathrm{~g} / \mathrm{kg} / 24 \mathrm{~h})$ and retained nitrogen (50-100 $\mathrm{mg} / \mathrm{kg} / 24 \mathrm{~h}$ ) well and on day 98 , weighing $10.4 \mathrm{~kg}$, he was changed to a varied diet. A few days later, because of persistent infection, a tonsillectomy was carried out. During the next 100 days, though clinically well, he did not gain weight but continued to increase in height at an accelerated rate. The second study was carried out on day 199 when height age was 19 months, weight age only 12 months, and he was on a casein diet.

Patient M7 was admitted to the hospital when he was 11 months old; height age 5.5 months $(66.8 \mathrm{~cm})$, weight age 2.5 months $(5.5 \mathrm{~kg})$, serum albumin concentration $3.93 \mathrm{~g} / 100 \mathrm{ml}$. Milk feedings were begun on day 3 and by the end of week 3 he was receiving $2.5 \mathrm{~g}$ protein and $150 \mathrm{kcal} / \mathrm{kg} / 24 \mathrm{~h}$, gaining weight slowly and retaining approximately $18 \%$ of ingested nitrogen, $72 \mathrm{mg} / \mathrm{kg} / 24 \mathrm{~h}$. The first study of body composition was made. On day 31 protein intake was reduced to $2.0 \mathrm{~g} / \mathrm{kg} / 24 \mathrm{~h}$; he now was gaining weight very rapidly and retaining $40 \%$ of ingested nitrogen, $130 \mathrm{mg} / \mathrm{kg} / 24 \mathrm{~h}$. On day 45 dietary protein was changed to a wheat-based product for 30 days, during which nitrogen retention decreased to $18 \%$ of intake, $90 \mathrm{mg} / \mathrm{kg} / 24 \mathrm{~h}$. Weight gain continued at an accelerated rate and serum albumin concentrations fell from 4.28 to $3.06 \mathrm{~g} / 100 \mathrm{ml}$. A succeeding 9-day period on milk protein resulted in $45 \%$ nitrogen retention, 145 $\mathrm{mg} / \mathrm{kg} / 24 \mathrm{~h}$, and partial correction of serum albumin concentration to $3.51 \mathrm{~g} / 100 \mathrm{ml}$.

On day 84 he was changed to a varied diet yielding approximately $3.0 \mathrm{~g}$ protein and $100 \mathrm{kcal} / \mathrm{kg} / 24 \mathrm{~h}$. Rate of weight gain decreased and serum albumin concentrations returned to more than $4.0 \mathrm{~g} / 100 \mathrm{ml}$. On hospital day 153, when height and weight ages were identical and he was on a casein diet, the second study of body composition was carried out.

Patient M8 had a chronologic age on admission of 9.5 months, height age 5 months $(64.2 \mathrm{~cm})$, weight age 2 months $(5.2 \mathrm{~kg})$, and a serum albumin concentration of $3.75 \mathrm{~g} / 100 \mathrm{ml}$. Milk was begun on day 1, and by day 29 , when the initial study of body composition was carried out, he was receiving $2.5 \mathrm{~g}$ protein and $150 \mathrm{kcal} / \mathrm{kg} / 24 \mathrm{~h}$, had just begun to gain weight and retained only $14 \%$ of ingested nitrogen $(58 \mathrm{mg} / \mathrm{kg} /$ $24 \mathrm{~h}$ ). On day 41 protein intake was reduced to $2.0 \mathrm{~g} /$ $\mathrm{kg} / 24 \mathrm{~h}$, and on day 51 dietary protein was changed to the whey-soy mixture for 37 days, during which weight gain was $5-6 \mathrm{~g} / \mathrm{kg} / 24 \mathrm{~h}$ and nitrogen retention about $100 \mathrm{mg} / \mathrm{kg} / 24 \mathrm{~h}$. During the next 2 months the diet provided $2 \mathrm{~g}$ milk protein and $125 \mathrm{kcal} / \mathrm{kg} / 24 \mathrm{~h}$. On day 156 intake was reduced to $100 \mathrm{kcal} / \mathrm{kg} / 24 \mathrm{~h}$, 
and on day 184 the source of protein was changed to an oat-soy mixture for 30 days, during which time he gained $1.6 \mathrm{~g} / \mathrm{kg} / 24 \mathrm{~h}$ and retained $80 \mathrm{mg} \mathrm{N} / \mathrm{kg} / 24 \mathrm{~h}$. On day 226, when height and weight ages were alike and he was on a casein diet, the second study of body composition was carried out.

Patient M9 was chronologically 4.5 months of age; height age 0.5 month $(52.5 \mathrm{~cm})$, weight age less than newborn $(2.72 \mathrm{~kg})$, serum albumin concentration 4.32 $\mathrm{g} / 100 \mathrm{ml}$. Milk feedings were begun immediately after the hormone studies and by the end of week 3 he was receiving $3.0 \mathrm{~g}$ protein and $150 \mathrm{kcal} / \mathrm{kg} / 24 \mathrm{~h}$, gaining weight steadily and retaining $31 \%$ of ingested nitrogen,
$153 \mathrm{mg} / \mathrm{kg} / 24 \mathrm{~h}$. The initial study of body composition was carried out.

On day 55 protein intake was reduced to $2.5 \mathrm{~g} / \mathrm{kg} /$ $24 \mathrm{~h}$. Fourteen days later protein was further reduced to $2.0 \mathrm{~g}$ and calorie intake to $125 \mathrm{kcal} / \mathrm{kg} / 24 \mathrm{~h}$. He continued to gain well and to retain $37.5 \%$ of nitrogen intake, $120 \mathrm{mg} / \mathrm{kg} / 24 \mathrm{~h}$. On day 93 he began 30 days on the whey-soy diet, during which time weight gain and nitrogen retention were only slightly lower than on milk protein. The second study of body composition was carried out on day 161, when weight age was 6.5 months, height age 5 months, chronologic age 10 months, and he had been on the casein diet for 38 days. 